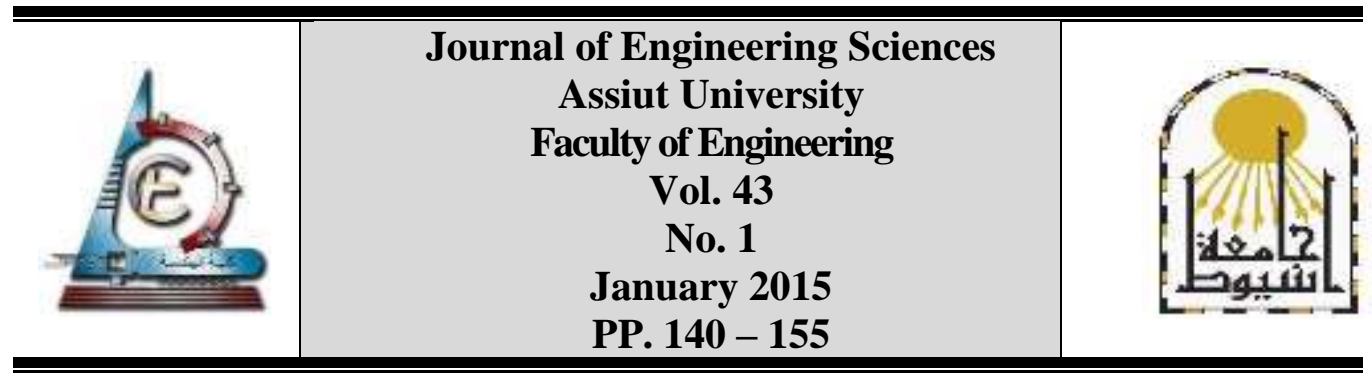

\title{
ASSESSING DISCREPANCIES IN CURRENT PRACTICES FOR SELECTING HEATING, VENTILATING AND AIR- CONDITIONING SYSTEMS IN BUILDINGS
}

\author{
Khodeir M. Laila \\ Department of Architecture-Faculty of Engineering, Cairo, Egypt \\ (Received 6 January 2015; Revised 26 January 2015; Accepted 11 February 2015)
}

\begin{abstract}
The selection process of heating, ventilating and air conditioning (HVAC) systems is a crucial process that irritates decision makers. In Egypt the selection process of such systems is mostly biased by the perception of the owner, his intuition and the pre- set budget by the manager. The non- objective decision making and the inappropriate selection of (HVAC) systems cause severe problems that range from changes in the space requirements to adapt with the chosen system, the provision of accessibility for maintenance and finally affecting their cost effectiveness. Both the architect and the electromechanical team are the primary stakeholders concerned with the actual selection process of the HVAC system. The divergence between their views is obvious in the methods and priorities of their selection process. Thus managing good understanding between the architect and the electromechanical team is crucial. This study intends to access the current practices used in the selection process of HVAC systems in buildings, through showing discrepancies among both perceptions; the architect's and the electromechanical. To achieve the objective of the paper a questionnaire was conducted. The target groups included students, graduates and experts in architecture and electromechanical disciplines. The results of this study showed remarkably how differences between the selection processes conducted by the target groups had a great impact on the efficiency of selected HVAC systems in buildings.
\end{abstract}

Keywords: HVAC Systems, Assessment, Current Practices, Egypt

\section{Introduction}

The selection process of heating, ventilating and air conditioning (HVAC) systems is a crucial process that irritates decision makers. This is because the contribution of buildings toward global energy consumption is approximately 40\% [1], where most of energy use in buildings is for the provision of heating, ventilation and air conditioning (HVAC), which takes about $50 \%$ of building energy consumption on average [2]. Thus, the selection of High-level performance of HVAC systems in building lifecycle is critical to building sustainability [3]. The role of HVAC systems is vital, since, if well designed and constructed, they can contribute to the reduction of the buildings' energy use and to the maintenance of an acceptable indoor air quality (IAQ) [4]. 
Several design parameters have a significant effect on the heating and cooling thermal loads of buildings. These parameters include the features of the building envelope (building shape, orientation, wall and roof constructions, window types and sizes), and the characteristics of (HVAC) systems (their type, efficiency and operation settings, [5]. All (HVAC) system designs should fulfil thermal comfort needs and indoor air quality, which are achieved by adjusting some parameters, considering energy savings. The design process is crucial in the accomplishment of those goals [6].

This paper examines the current practices and analyses of the parameters that guide the selection process of such vital systems from both views of the architectural designer and the electromechanical engineer, who represent the primary stakeholders concerned with the actual selection process of HVAC systems.

\subsection{Problem definition}

This paper is concerned with accessing the current practices process of HVAC systems in buildings. In Egypt, this process is mostly dependent on the perception of the owner, his intuition and the budget determined in advance by the manager. This non-objective selection of (HVAC) systems causes severe problems, such as changes in the space requirements to adapt with the chosen system, the provision of accessibility for maintenance and finally affecting their cost effectiveness.

In addition to the problems resulting from the owner perception, the divergence between both the views of the designer of the building and the electromechanical forms another problem. This divergence is obvious in the methods and priorities of their selection process. While the main concern of the architect is to accomplish his design concept with zero modifications, the electromechanical is much concerned about calculations and the provision of enough spaces for the selected system.

\subsection{Objectives}

This study intends to access the current practices used in the selection process of HVAC systems in buildings, through showing discrepancies among both perceptions; the architect's and the electromechanical. Several design parameters that have a significant effect on the selection of heating and cooling thermal loads of buildings are investigated. These parameters are examined and prioritized from both views of the architect and the electromechanical, in order to achieve better understanding between the architect and the electromechanical team.

\section{Methodology}

Primary data were collected by questionnaires and in-depth interviews and secondary data were gathered by observations and analysis. A household drop-off survey was adopted in this paper, where the researcher went to the respondent's business and hands him the questionnaire. Some of the respondents were asked to mail it back; in other cases, the researcher returned to pick it up. This approach attempts to blend the advantages of the mail survey and the group-administered questionnaire [7]. In addition, open interviews were held with electromechanical experts while the questionnaires targeted the architects. 
Khodeir M. Laila, assessing discrepancies in current practices for selecting heating, ventilating ...

\subsection{Types of respondents}

Although the selection process of HVAC systems in buildings is relevant to different stakeholders including client groups, design team, project management team and electromechanical team, the current research concentrated on two categories of respondents: architectural designers and electromechanical experts.

Three groups of variables were categorized to test differences in the opinions of respondents. These were: the working experience of the respondent (whether juniors or seniors), the respondent's job position (whether an architect or an electromechanical) and the type of projects that the respondent frequently carry out.

\section{- Work experience}

Two categories of respondents based on work experience are represented to be more than or equal 10 years of working experience, while the other group is less than 10 years of working experience.

\section{- Job position}

A wide range of job position groups are included in this study; these groups are architecture design fresh-graduates, expert architecture designers, expert electromechanical engineers and academics who are also working as architects or consultants and nonacademic consultants.

\section{- Type of projects}

This variable includes different types of construction projects, whether public-owned projects or private- owned ones, which the respondent has frequently carried out or shared in.

\subsection{The Design of questionnaire}

When you submit your final version, after your paper has been accepted, prepare it in two-column format, including figures and tables.

The questions included in the questionnaire were designed through a brainstorming process that involved three different experts: an academic architecture stuff member, an academic electromechanical stuff member and a senior electromechanical engineer who has 11 years of experience working in HVAC systems design. The questionnaire included different types of questions, such as:

- Ordinal questions: The respondents were asked to order their preference for different aspects using ordinal questions, where 1 is the respondent's first choice showing his/her first priority.

- Interval questions: where 1-to-5 rating is adopted. This is applied to some opinion questions.

- Filter or Contingency Questions: the questionnaire involved multiple questions of that type to determine if the respondents are qualified or experienced enough to answer the rest of the questionnaire or not.

\subsection{The Response format}

Both structured and unstructured response formats were adopted in this questionnaire. Structured format, in some cases, helped the respondent to respond more easily and helped the researcher to accumulate and summarize responses more efficiently. Meanwhile in the unstructured format, used, the respondent wrote down his response in the form of a text, which gave a full view of his response [7]. 


\subsection{Analysis of data}

A total of 50 questionnaires were distributed on the different target groups, a return rate was about $65 \%$, and a variety of years of experience groups between 1 and 44 years were included in this investigation. Ages of respondents ranged from 22 to 65 . All respondents had at least a bachelor degree, 4 of them were PHD holders and 3 were master degree holders.

\section{Selection parameters of HVAC systems}

This paper suggests four main parameters that guide the selection process of HVAC system. These parameters include: background knowledge of the architect, addressing sustainability issues, efficient coordination and the selection of efficient systems.

The criteria that guide the selection process of HVAC systems vary from the point of view of different stakeholders. The electro-mechanicals make their selection based on a group of factors. These factors include the initial and life-cycle cost, suitability for the intended occupancy, floor space requirements, maintenance, reliability, simplicity and control [8]. In addition, the selection of the system should be governed by the most efficient use of available natural resources.

\subsection{The Background knowledge}

The structure of architects' professional knowledge and the way it is related to experience, is considered an interesting issue to be investigated. The architect is asked to have equal background on multidisciplinary frameworks, including artistic, scientific, economic and technological disciplines. Thus, the architect is therefore constantly required to integrate both theoretical knowledge and practical experience at work.

Although it is not the main role of the architect to decide about the HVAC system to be used in their designed building, they should have the minimum knowledge about the different requirements of the systems. These requirements include space requirements for equipment's, energy use, maintenance and operational requirements, in addition to cost requirements.

Moreover, the architect should have the knowledge to allocate adequate space for the mechanical equipment, pipelines and ducts, from the preliminary stages of the design process. They should be aware of the main rules of a thumb for such tasks, and must also consider the coordination of the position of devices to avoid different consequences of skipping that.

\subsection{Addressing sustainability issues}

Sustainability policy is a very important issue to discuss and apply. It has many paths and any improvement in external walls, glass, roof or inner partition construction extremely affects the HVAC system, which reflects deeply on electrical consumption. Both the architect and the electro- mechanical consultant should evaluate several alternatives related to the optimization of the thermal regulation capability of the building, the level of insulation, the extents of shading and many other attributes related to sustainability and conservation of energy [8]. 
Khodeir M. Laila, assessing discrepancies in current practices for selecting heating, ventilating ...

\subsection{Efficient coordination}

The architect and the electromechanical should be able to efficiently coordinate with each other to achieve better process of HVAC system selection and accomplish a win-win scenario. In addition, a cost-effectiveness analysis, between different active and passive approaches in design and their impact on the overall cost of systems, should be conducted [8].

The best time to achieve efficient coordination between the architect and the electromechanical consultant is the early beginning of the project, which guarantees minimum further modifications of spaces afterwards.

\subsection{Selection of efficient systems}

In the past or even now, most of the HVAC systems are selected purely on basis of the lowest tender prices, even though they are required to be undergone the pre-qualification process [9]. However, it is increasingly admitted that the practice of awarding tenders on a basis of low tender price eventually would lead to the ultimate quality problems.

\section{Data collection}

The process of data collection was based on using a designed questionnaire that targeted architects of differed ages, levels of experience and background knowledge. The main parts of the questionnaire are discussed in the next part of the paper.

\subsection{Profile of respondents}

This part included general data about the respondent, including gender, education, age, years of experience and types of projects most frequently carried out.

\subsection{Background knowledge}

This part included examining the background of the respondents, Table (1).

Table 1.

The objectives/ measured attribute in each group of background knowledge questions (Source: The author)

\begin{tabular}{|l|l|}
\hline Objective of question/measured attribute & Question \\
\hline $\begin{array}{l}\text { The best time of thinking about the } \\
\text { appropriate HVAC system and } \\
\text { involving the HVAC consultant. }\end{array}$ & $\begin{array}{l}\text { At what stage of the project do you often } \\
\text { involve HVAC consultants? } \\
\text { At what stage do you start thinking about the } \\
\text { appropriate HVAC system? }\end{array}$ \\
\hline $\begin{array}{l}\text { How far does the architect involve } \\
\text { spaces in his design for both HVAC } \\
\text { systems requirements and for the } \\
\text { accessibility of maintenance as well? }\end{array}$ & $\begin{array}{l}\text { Do you usually involve enough spaces for HVAC } \\
\text { systems requirements in your design? } \\
\text { Do you usually consider the access to the HVAC } \\
\text { equipment for fulfilling maintenance in your design? }\end{array}$ \\
\hline
\end{tabular}




\begin{tabular}{|c|c|}
\hline Objective of question/ measured attribute & Question \\
\hline $\begin{array}{l}\text { The rules of a thumb of calculating and } \\
\text { allocating the space of the machine } \\
\text { room with respect to floor area. }\end{array}$ & $\begin{array}{l}\text { What is the area percentage that HVAC machine } \\
\text { rooms occupy with respect to the floor areas that } \\
\text { they service? (In case of using central system) } \\
\text { If HVAC distribution system is air system, } \\
\text { what is the case area allocated for duct risers } \\
\text { for each } 100 \mathrm{~m}^{2} \text { of floor area that they service? } \\
\text { How often do you locate HVAC equipment in } \\
\text { roof penthouse room? }\end{array}$ \\
\hline Verification questions. & $\begin{array}{l}\text { 1- How often do you apply modifications on the } \\
\text { design after the HVAC system has been chosen? } \\
\text { Describe the modifications you apply on your } \\
\text { design after the interference of the } \\
\text { electromechanical team. }\end{array}$ \\
\hline
\end{tabular}

\subsection{Sustainability}

This part included examining the degree of awareness of the respondent towards the impact of sustainability on the system selection, Table (2).

\section{Table 2.}

The objectives/ measured attribute in each group of sustainability knowledge questions (Source: The author)

\begin{tabular}{|l|l|}
\hline Objective of question/measured attribute & \multicolumn{1}{|c|}{ Question } \\
\hline $\begin{array}{l}\text { The degree of involvement of } \\
\text { sustainability design on the building. }\end{array}$ & $\begin{array}{c}\text { - How often do you adopt sustainability concepts in } \\
\text { your designs? } \\
\text { Please, Rank the following passive methods from the } \\
\text { most used to the least used in your designs (do not give } \\
\text { a rank to the systems you do not use }\end{array}$ \\
\hline $\begin{array}{l}\text { The depth and scope of the } \\
\text { respondent's knowledge about different } \\
\text { passive treatments that affect the } \\
\text { conservation of energy in the buildings. }\end{array}$ & $\begin{array}{l}\text { - What type of passive method do you use in Upper Egypt? } \\
\text { thermal insulator in your building design? } \\
\text { - How often do you use roof gardens in your building design? }\end{array}$ \\
\hline $\begin{array}{l}\text { Measuring the degree of awareness } \\
\text { towards conscious choice of materials. }\end{array}$ & $\begin{array}{l}\text { - How often are your choices of building materials } \\
\text { based on life-cycle cost? }\end{array}$ \\
\hline $\begin{array}{l}\text { Verification questions aiming at making } \\
\text { sure that the respondent answered frankly } \\
\text { to the previously asked question. }\end{array}$ & $\begin{array}{l}\text { - How often do you involve passive cooling methods in } \\
\text { your work? }\end{array}$ \\
\hline
\end{tabular}

\subsection{Coordination}

This part of the questionnaire included examining the degree of coordination of the respondent with other partners who share in the selection process of HVAC systems, table (3).

\footnotetext{
${ }^{1}$ - These data and calculations were based on empirical methods that are widely approved by the electromechanical experts working in the field of HVAC systems design in Egypt, in addition to [10].
} 
Khodeir M. Laila, assessing discrepancies in current practices for selecting heating, ventilating ...

\section{Table 3.}

the objectives/ measured attribute in each group of coordination questions Source: The author

\begin{tabular}{|l|l|}
\hline Objective of question/measured attribute & Question \\
\hline $\begin{array}{l}\text { Evaluating the type of relationship } \\
\text { between the architect and the } \\
\text { electromechanical }\end{array}$ & $\begin{array}{l}\text { How often do you have problems with the } \\
\text { electromechanical team? } \\
\text { Rank the following problems that might have faced } \\
\text { you while dealing with the electromechanical (From } \\
\text { the most repetitive (1) to the least (5) (do not give a } \\
\text { rank to the problems you never had) }\end{array}$ \\
\hline Verification questions & $\begin{array}{l}\text { Does the electromechanical team who works with you } \\
\text { complain about having difficulties in your designs? } \\
\text { If ever, in what stage does the electro mechanical's } \\
\text { complaint appear? } \\
\text { What type of modifications do you need to apply } \\
\text { after the electromechanical Interference? }\end{array}$ \\
\hline
\end{tabular}

\subsection{Selection of qualified people and systems}

This part of the questionnaire included examining the methods of selection of HVAC systems and contractors, table (4).

\section{Table 4.}

the objectives/ measured attribute in each group of contractors and system selection questions (Source: the author)

\begin{tabular}{|l|l|}
\hline Objective of question/measured attribute & Question \\
\hline $\begin{array}{l}\text { Determining the factors affecting the choice of the } \\
\text { HVAC contractor from the respondent's point of view }\end{array}$ & $\begin{array}{l}\text { 2- What are the qualifications that determine } \\
\text { the choice of HVAC contractor? }\end{array}$ \\
\hline $\begin{array}{l}\text { Determining and rating the methods used for } \\
\text { the choice of the HVAC system from the } \\
\text { architect's point of view. }\end{array}$ & $\begin{array}{l}\text { 1- How, and how often, do you actually } \\
\text { choose the HVAC system? }\end{array}$ \\
\hline $\begin{array}{l}\text { Determining and rating the criteria used for } \\
\text { the choice of the HVAC system from the } \\
\text { respondent's point of view }\end{array}$ & $\begin{array}{l}\text { 2- Please rank the following criteria that guide } \\
\text { your choice of the HVAC system }\end{array}$ \\
\hline $\begin{array}{l}\text { The relationship between the type of building } \\
\text { and the selected HVAC system from the } \\
\text { respondent's point of view. }\end{array}$ & $\begin{array}{l}\text { 3- Please specify the HVAC system you } \\
\text { mostly apply for each of the following } \\
\text { building types }\end{array}$ \\
\hline
\end{tabular}

\section{General results}

Based on the analysis of the questionnaires' results of consultants, architects and interviewing electromechanical experts, the following attributes for the selection process of HVAC systems in buildings were deducted.

\subsection{Attributes of system selection from the architects point of view}

The following part describes the general results extracted from the questionnaire that was applied on a group of architects who have different background knowledge, years of experience and practices.

${ }^{2}$ - The choice of the right system is the outcome of different factors, but the answers to this question mainly depends on the individual experience of the interviewee. 


\subsubsection{Profile of respondents}

The general features concerning the profile of respondents are shown in table (5). These features show that while both junior males and females are involved in the selection of HVAC systems, all the senior architects involved in such process are males. This indicates the general trend found in Egypt and the general preferences of both genders.

\subsubsection{Background knowledge}

This part of the analysis included investigating the time of selecting HVAC systems, figure (1), fulfilling their space requirements, figure (2), considering the accessibility for maintenance of system, figure (3) and checking the rules of thumb of system-related calculations by both junior and senior architects, figure (4).

\section{Table 5.}

General features of the profile of respondents questions

\begin{tabular}{|l|c|c|}
\hline Profile of Respondents & Junior Arch. & Senior Arch \\
\hline Gender & $50 \%$ & $100 \%$ \\
\hline Years of experience & Fresh graduates to 9years' experience & From 10 to 44 years of experience \\
\hline $\begin{array}{l}\text { Type of projects frequently } \\
\text { carried out }\end{array}$ & $\begin{array}{c}\text { Sport facilities, community } \\
\text { centers, educational buildings, } \\
\text { service buildings and airports }\end{array}$ & $\begin{array}{c}\text { Office buildings, malls, residential } \\
\text { buildings, medical centers, touristic } \\
\text { projects and cultural centers }\end{array}$ \\
\hline
\end{tabular}

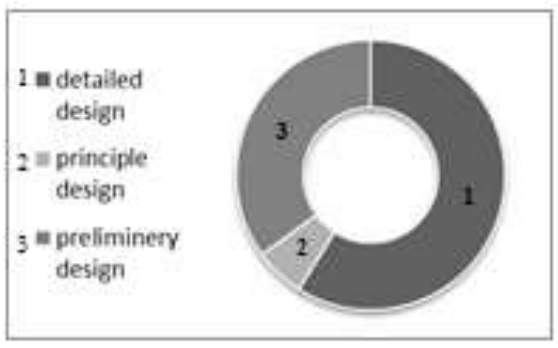

Fig. (1. a.) according to junior architects

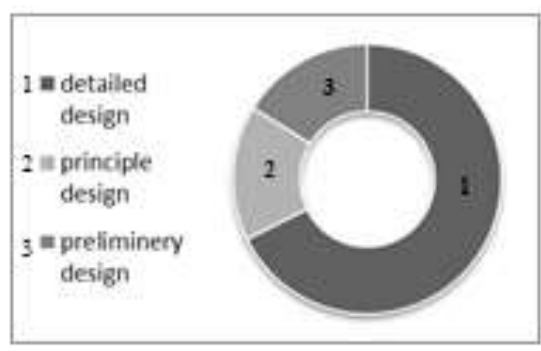

Fig. (1. b.) according to senior architects

Fig. 1. The timing of HVAC system selection

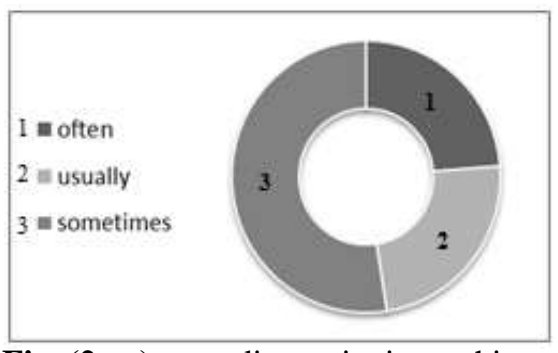

Fig. (2. a.) according to junior architects

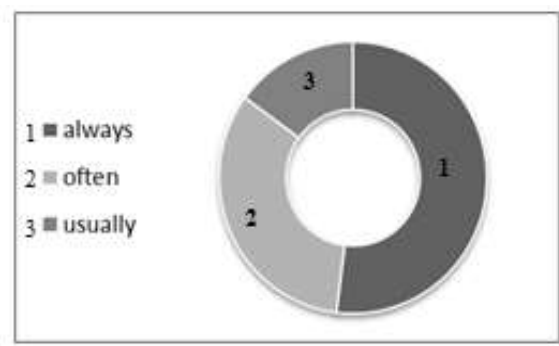

Fig. (2. b.) according to senior architects

Fig. 2. The rate of including enough spaces for the selected system 
Khodeir M. Laila, assessing discrepancies in current practices for selecting heating, ventilating ...

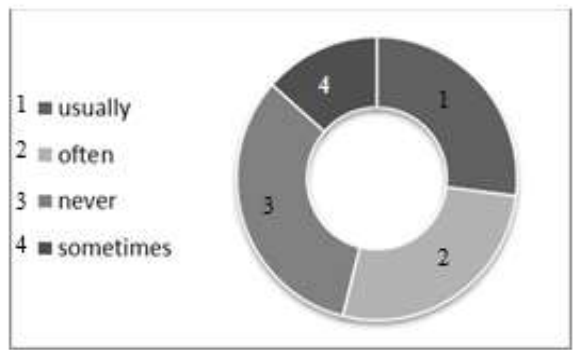

Fig. (3. a.) according to junior architects

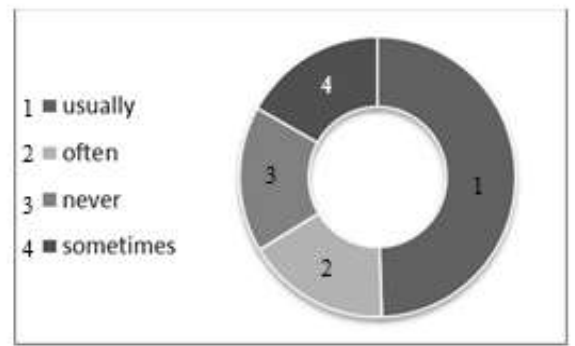

Fig. (3. b.) according to senior architects

Fig. 3. considering accessibility for maintenance of the selected system according to architects

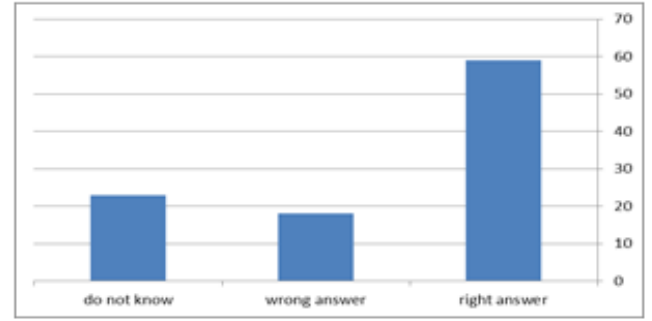

Type of response

Fig. (4. a.) according to junior architects
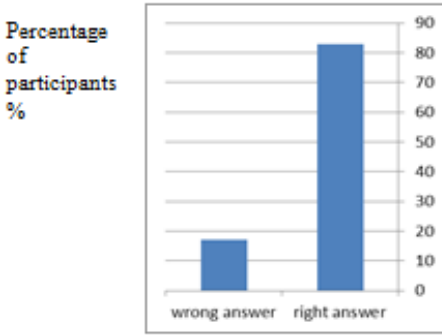

Type of response
Percentage

of participants

$\%$

Fig. (4. b.) according to senior architects

Fig. 4. Rules of a thumb for system-related calculations according to architects

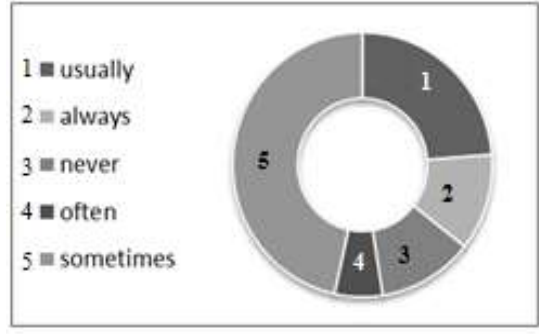

Fig. (5. a.) according to junior architects

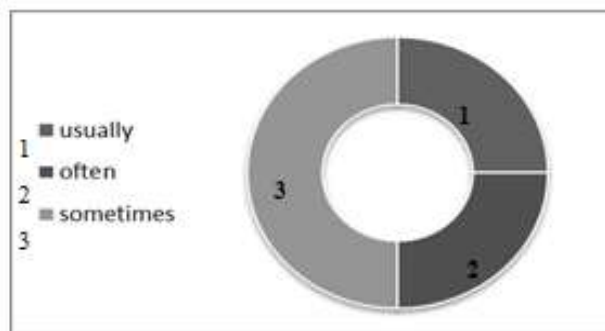

Fig - (5. b.) according to senior architects

Fig. 5. rate of applying sustainability concepts

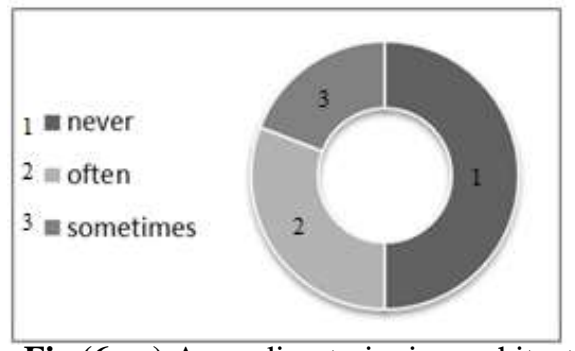

Fig.(6. a.) According to junior architects

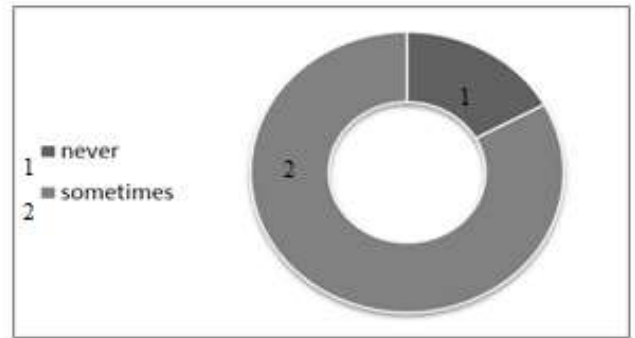

Fig. (6. B.) according to senior architects

Fig. 6. rate of applying roof gardens and vertical landscaping according to architects 


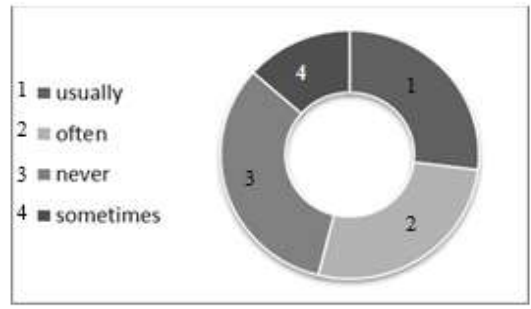

Fig. (7. a.) according to junior architects

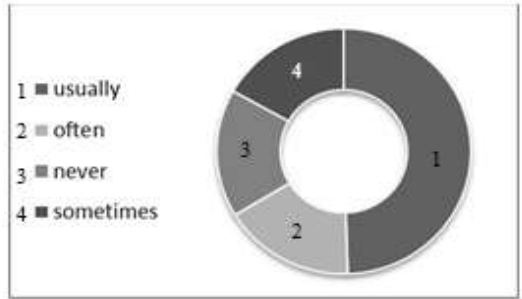

Fig. (7. b.) according to senior architects

Fig. 7. including the impact of LCC ( Life Cycle Analysis) on the choice of building materials, according to architects

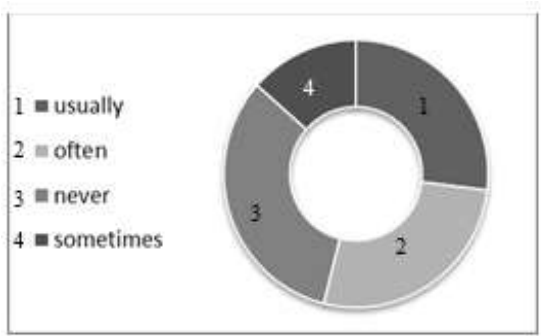

Fig. (8. a.) according to junior architects

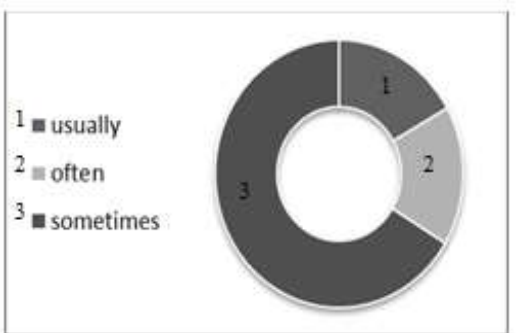

(Fig.8.b.) according to senior architects

\subsubsection{Sustainability}

Fig. 8. according to senior architects

This part of the analysis examined the rate of applying the concepts of sustainability in design of buildings, figure (5), the awareness of both junior and senior architects of some major sustainable strategies such as roof gardens, figure (6), the impact of Life Cycle Analysis (LCC) on the choice of building materials, figure (7), and the rate of applying passive cooling strategies, figure (8). Table (6) shows a general ranking for the passive design strategies from the most effectively applied (rank 1) to the least applied (rank 6).

\section{Table 6.}

Ranking of passive design strategies

\begin{tabular}{|l|c|c|c|c|}
\hline \multicolumn{1}{|c|}{ Passive method } & $\begin{array}{c}\text { juniors } \\
\text { ranking }\end{array}$ & $\begin{array}{c}\text { seniors } \\
\text { ranking }\end{array}$ & $\%$ & Final ranking \\
\hline Natural ventilation & 1 & 1 & $50 \%$ & 1 \\
\hline Thermal masses & 4 & 2 & $33 \%$ & 3 \\
\hline Evaporative cooling & 5 & 6 & $83 \%$ & 5 \\
\hline Passive solar Heating & 4 & 3 & $50 \%$ & 4 \\
\hline Shading & 3 & 2 & $67 \%$ & 2 \\
\hline Vertical landscaping & 5 & 6 & $100 \%$ & 6 \\
\hline Green roof & 6 & 4 & $33 \%$ & 5 \\
\hline
\end{tabular}

\subsubsection{Coordination}

This part of the analysis examines the degree of coordination between the architect and the electromechanical. The efficiency of coordination could be traced from both the rate of 
Khodeir M. Laila, assessing discrepancies in current practices for selecting heating, ventilating ...

complaint of the electromechanical, figure (9), and the phase at which complaints occur, figure (10). Starting this part of the study the results demonstrated are restricted to senior architects only, as the contingency questions have shown inconveniencies amongst the results of junior architects. This has to do with the lack of enough experience and the limitation of their practice.

\subsubsection{Selection of efficient systems}

This part of the analysis concludes the internal factors affecting the choice of the HVAC contractor from the senior architects' point of view, table (7).

Table7 .

Factors affecting system selection

\begin{tabular}{|l|l|l|}
\hline table7: factors affecting system selection \\
\hline Method of choice & $\begin{array}{l}\text { Never /Sometimes (negative } \\
\text { answer) }\end{array}$ & $\begin{array}{l}\text { often/always (positive } \\
\text { answer) }\end{array}$ \\
\hline Your own knowledge & $67 \%$ & $33 \%$ \\
\hline Consulting an electromech. expert & $44 \%$ & $56 \%$ \\
\hline Consulting academic professors & $75 \%$ & $25 \%$ \\
\hline
\end{tabular}

\subsection{Attributes of system selection from the electromechanical point of view}

The following part describes the results extracted from the in-depth interview that was applied on a number of electromechanical experts who have more than ten years of experience in the field of the design of HVAC buildings in buildings.

Table (8) shows the problems most of the electromechanical interviewees mentioned in different design phases and their rating from the most severe (1) to the least severe (5). Most of the electromechanical interviewees mentioned that they "always" have problems with the architects and that they "usually" complain about difficulties in the architectural design concerning the design and allocation of HVAC systems.

\section{Table 8.}

The problems electro mechanicals have in different design phases and their rating

\begin{tabular}{|c|l|l|}
\hline Phase of design & Problem description & rating \\
\hline principle design & $\begin{array}{l}\text { Convincing the project manager and the architectural team of the } \\
\text { most proper HVAC system which suits the project's demands and } \\
\text { the circumstances of the site. }\end{array}$ & 3 \\
\hline Preliminary design & $\begin{array}{l}\text { Providing mechanical rooms with certain areas and shafts for air } \\
\text { ducts and pipes. } \\
\text { Making two-dimensional drawings for ducts routings while } \\
\text { allocating all HVAC equipment. }\end{array}$ & 2 \\
\hline Detailed design & $\begin{array}{l}\text { The inefficient coordination, conflict with structural openings, false } \\
\text { ceiling height and air outlets and the lack of reflection of some } \\
\text { requirements on plans either from the architectural or from the } \\
\text { electromechanical team. }\end{array}$ & 1 \\
\hline $\begin{array}{c}\text { Construction } \\
\text { documents }\end{array}$ & $\begin{array}{l}\text { If the previous problems were resolved, this phase would pass with } \\
\text { great convenience and minimum changes. }\end{array}$ & 4 \\
\hline
\end{tabular}




\section{Findings}

The main findings of this paper are concerned with showing the discrepancies of the selection process of HVAC systems amongst both groups: the architects and the electro mechanicals. These discrepancies represent indicators that could anchor in the assessment of current practices of selecting HVAC systems in buildings.

\subsection{Problems affecting the selection of HVAC systems}

Regarding the problems linked to the selection of HVAC systems, both groups agreed that affording enough clear ceiling height to adopt fittings of the system and the electric power consumption of the system are the most devastating problems they both have. The two groups have shown variation in their view of the impact of the problem of noise generated from the selected system. While the electromechanical considered this a problem of moderate impact, the architect classified it as a low-impact problem on system selection. Table (9) shows the ranking of the top HVAC systems - related problems from the top major problem (rank 1) to the least minor problem according to both target groups.

\section{Table 9.}

\section{Ranking common problems linked to HVAC system selection}

\begin{tabular}{|l|c|c|c|}
\hline $\begin{array}{l}\text { Problems related to HVAC } \\
\text { system selection }\end{array}$ & $\begin{array}{c}\text { problems ranking } \\
\text { according to } \\
\text { Architects }\end{array}$ & $\begin{array}{c}\text { problems ranking } \\
\text { according to electro } \\
\text { mechanicals }\end{array}$ & \\
\hline Clear ceiling height & 1 & 1 & 2 \\
\hline Air duct layout & 3 & 1 & \\
\hline Equipment location & 2 & 3 & \\
\hline Air outlet location & 4 & 4 & \\
\hline Noise generated & 6 & 5 & \\
\hline Electric power consumption & 5 & & \\
\hline
\end{tabular}

\subsection{Factors affecting the choice of HVAC systems}

Table (10), shows the summery of the results concerning the factors that affect the choice of the HVAC system from the view of both groups. While architects considered the most important factors affecting their choices to be maintainability and reliability, electro mechanicals considered low initial cost and system the most vital factors affecting their choices. The ranking of used criteria ranges from the most impacting factors (rate 1) to the least impacting factors (rate 7).

\subsection{The Impact of the type of building on the selection of HVAC system}

According to the results shown in table (10), Architects consider the impact of the type of building on the selected system a vital factor; meanwhile, electro mechanicals consider it a factor of low impact on the selection process of HVAC systems. Nevertheless, figure (9) shows the degree of agreement among both groups on the types of HVAC systems that they commonly use in distinctive types of buildings. This figure shows that both groups agreed upon using the same type of HVAC systems in hospital buildings, and they partially agreed on the types of systems used in hotel buildings and high-rise office buildings. Both groups 
Khodeir M. Laila, assessing discrepancies in current practices for selecting heating, ventilating ...

had great differences in their opinion concerning the HVAC systems they commonly use in educational buildings and low-rise office buildings. Appendix (1), shows the exact systems selected by each target group in each type of building.

\section{Table 10.}

Ranking the criteria affecting the selection of the HVAC contractor from both the architect and the electromechanical points of view

\begin{tabular}{|l|l|l|}
\hline $\begin{array}{l}\text { Major Criteria affecting the selection } \\
\text { of HVAC systems }\end{array}$ & $\begin{array}{l}\text { Ranking of selection } \\
\text { factors according to } \\
\text { architects }\end{array}$ & $\begin{array}{l}\text { Ranking of selection factors } \\
\text { according to electro } \\
\text { mechanicals }\end{array}$ \\
\hline Availability in the Egyptian market & 3 & 2 \\
\hline $\begin{array}{l}\text { Energy consumption vs. energy } \\
\text { savings }\end{array}$ & 5 & 5 \\
\hline Maintainability of system & 1 & 3 \\
\hline Reliability of the system & 2 & 6 \\
\hline Low initial costs & 6 & 1 \\
\hline Low life cycle cost & 7 & 4 \\
\hline Suitability with building type & 4 & 7 \\
\hline
\end{tabular}

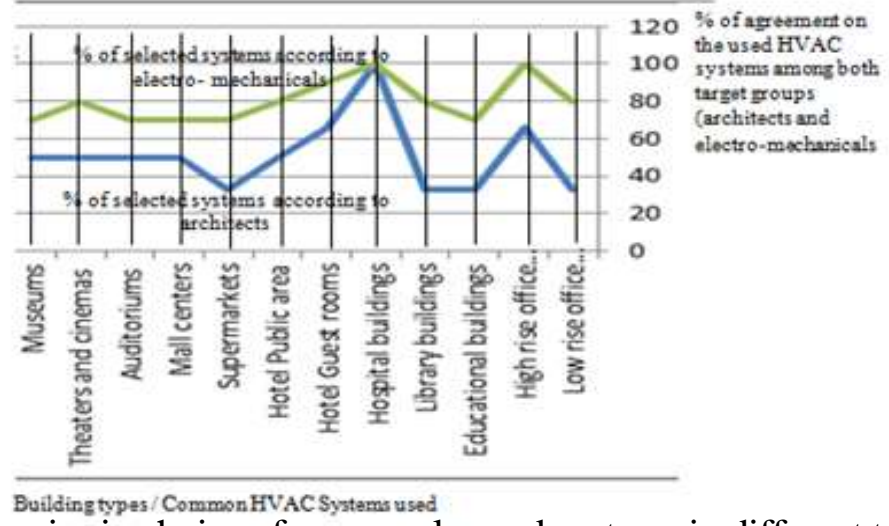

Fig. 9. discrepancies in choice of commonly used systems in different types of buildings

\section{Conclusions}

The selection process of HVAC systems in buildings in Egypt is greatly affected by the current practices performed by both architects and electro mechanicals.

- According to this study, though most architects believe that the involvement of the electromechanical should be considered in the detailed design phase, the electro mechanicals believe they should be involved in the preliminary phases of the design process; they added that their late involvement leads to most of their complaints.

- Although most architects mentioned that they always/often include enough spaces for HVAC system requirements, figure (2), the electro mechanicals categorized the problem of affording enough clear ceiling height, and enough location for HVAC system equipment as a top major problem that they often face (table 9).

- While most of the senior architects were able to calculate the space requirements of HVAC systems using rules of thumb extracted from their own practices, junior architects found it hard to perform such calculations correctly. This probably indicates a problem in the efficiency of the academic courses that address the design of HVAC systems they had in college.

- There is an obvious gap between the opinions of both groups concerning the rate of having problems in the coordination phase. Most senior architects claimed they never had problems 
with electro mechanicals, meanwhile most electro mechanicals claimed they always have problems in coordinating with architects.

Finally, the paper proved that both groups have shared some common practices and discrepancies concerning the selection process of HVAC systems, this was clearly expressed in their views of the problems, factors and types of buildings that mostly affect selection process.

\section{Recommendations}

This paper suggests a number of recommendations that addresses both the architects and the electro mechanicals that are involved in the selection process of HVAC systems. These recommendations aim at improving the current practices implemented in this process:

- Including early involvement of the HVAC consultants.

- Revising calculations of the mechanical room carefully by both the architect and the electromechanical to afford enough space for maneuvering and maintaining equipment.

- Emphasizing Sustainability policies (which would deeply reflect on the electric consumption of HVAC systems).

\section{REFERENCES}

[1] Omer AM. (2008), Energy, environment and sustainable development. Renew Sustainable Energy Rev, 12 (9): 2265-3000.

[2] Perez-Lombard L, Ortiz j, Pout C.( 2007) A review on buildings energy consumption Information. Energy Building: 10.1016/j.enbild. 2007.03.007.

[3] Fu Xiao, Shengwei Wang (2009) Progress and methodologies of lifecycle commissioning of HVAC systems to enhance building sustainability - Elsevier- Renewable and Sustainable Energy Reviews 13 [1144-1149].

[4] M. Orme, (2001), Estimates of the energy impact of ventilation and associated financial expenditures, Energy and Buildings 33 199-205.

[5] Youssef Bichiou and Moncef Krarti (2011), Optimization of envelope and HVAC systems selection for residential buildings- Energy and Buildings 43, 3373-3382.

[6] Miguel Cavique A.M. Goncalves Coelho (2009), Axiomatic design and HVAC systems: An efficient design decision-making criterion - Energy and Buildings 41, 146-153.

[7] Research methods knowledge based-http://www.socialresearchmethods.net/kb/survwrit.php$1 / 1 / 2013$.

[8] P.E.,Vaughn Bradshaw (2006), The Building Environment, John Wiley \& Sons, 3rd Ed.

[9] C.K. Chau, W.L. Sing and T.M. Leung (2002), An analysis on the HVAC maintenance contractors selection process, Elsevier, 12 September 2002.

[10] ASRAE (2009), Fundamentals, American Society of Heating, Refrigerating and AirConditioning Engineers, Inc., http://www.ashrae.org.

APPENDIX (1): shows the exact results of the HVAC systems selected by each target group in each type of building.

$\begin{array}{llll}\text { Type of building } & \begin{array}{l}\text { architecture HVAC } \\ \text { choices }\end{array} & \begin{array}{l}\% \text { of } \\ \text { senior }\end{array} & \begin{array}{l}\text { electromechanical } \\ \text { HVACsystems choices }\end{array} \\ \begin{array}{l}\text { Low rise office } \\ \text { buildings }\end{array} & \text { DX, VRF, split } & 33 \% & \text { VRF,DX or air cooled chiller } \\ \begin{array}{l}\text { High rise office } \\ \text { buildings }\end{array} & \begin{array}{l}\text { Central water cooled } \\ \text { Central air cooled }\end{array} & 33 \% & \text { prim. sec.air cooled or water } \\ & \% 33 & \text { cooled chiller sys }\end{array}$


Khodeir M. Laila, assessing discrepancies in current practices for selecting heating, ventilating ...

\begin{tabular}{|c|c|c|c|}
\hline $\begin{array}{l}\text { Educational } \\
\text { buildings }\end{array}$ & $\begin{array}{l}\text { Central water cooled } \\
\text { DX + SPLIT } \\
\text { Central air cooled + split }\end{array}$ & $\begin{array}{l}17 \% \\
33 \% \\
17 \%\end{array}$ & VRF, DX system \\
\hline Library buildings & $\begin{array}{l}\text { Central air cooled }+ \text { split } \\
\text { Central water cooled } \\
\text { DX + SPLIT }\end{array}$ & $\begin{array}{l}33 \% \\
17 \% \\
17 \%\end{array}$ & $\begin{array}{l}\text { Air cooled chillers with sound } \\
\text { attenuators, VRF }\end{array}$ \\
\hline $\begin{array}{l}\text { Hospital } \\
\text { buildings }\end{array}$ & $\begin{array}{l}\text { Central air cooled } \\
\text { Central water cooled }+ \text { split }\end{array}$ & $\begin{array}{l}67 \% \\
17 \%\end{array}$ & Water or air cooled chillers sys. \\
\hline $\begin{array}{l}\text { Hotel Guest } \\
\text { rooms }\end{array}$ & $\begin{array}{l}\text { Central air cooled }+ \text { split } \\
\text { Central water cooled }\end{array}$ & $\begin{array}{l}33 \% \\
33 \%\end{array}$ & Water or air cooled chillers sys \\
\hline Hotel Public area & $\begin{array}{l}\text { Central air cooled } \\
\text { Central water cooled }\end{array}$ & $\begin{array}{l}33 \% \\
17 \%\end{array}$ & Water or air cooled chillers sys \\
\hline Supermarkets & $\begin{array}{l}\text { Central air cooled }+ \text { split } \\
\text { Central Water cooled }\end{array}$ & $\begin{array}{l}33 \% \\
17 \%\end{array}$ & Package DX system \\
\hline Mall centers & $\begin{array}{l}\text { Central air cooled } \\
\text { Central water cooled }\end{array}$ & $\begin{array}{l}33 \% \\
17 \%\end{array}$ & $\begin{array}{l}\text { DX syetm, Water or air cooled } \\
\text { chillers sys }\end{array}$ \\
\hline Auditoriums & $\begin{array}{l}\text { Central air cooled } \\
\text { Central water cooled }\end{array}$ & $\begin{array}{l}33 \% \\
17 \%\end{array}$ & Water or air cooled chillers sys \\
\hline $\begin{array}{l}\text { Theaters and } \\
\text { cinemas }\end{array}$ & $\begin{array}{l}\text { Central air cooled } \\
\text { VRF units }\end{array}$ & $\begin{array}{l}33 \% \\
17 \%\end{array}$ & $\begin{array}{l}\text { Water or air cooled chillers sys, } \\
\text { Package DX }\end{array}$ \\
\hline Museums & $\begin{array}{l}\text { Central air cooled } \\
\text { Central water cooled }\end{array}$ & $\begin{array}{l}33 \% \\
17 \%\end{array}$ & $\begin{array}{l}\text { VRF,DX package units, Water } \\
\text { or air cooled chillers sys }\end{array}$ \\
\hline Mall shops & Central air cooled + split & $50 \%$ & $\begin{array}{l}\text { VRF,DX package units, or air } \\
\text { cooled chillers sys }\end{array}$ \\
\hline
\end{tabular}




\section{تقييم التناقضات في الممارسات المتعلقة باسس اختيار انظمة التكييف في المباني}

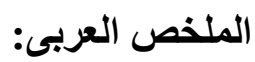

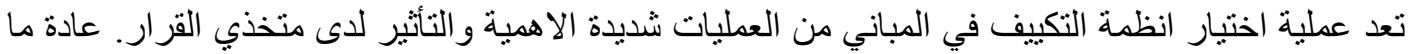

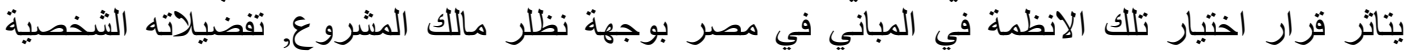

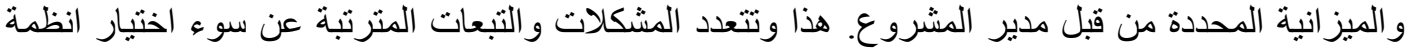

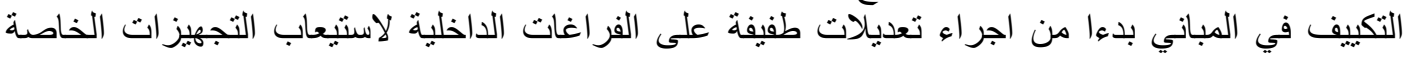

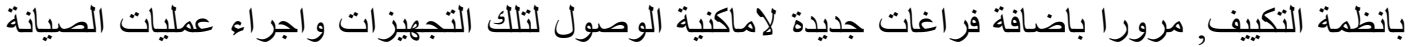

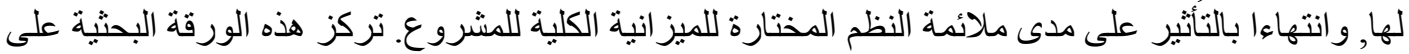

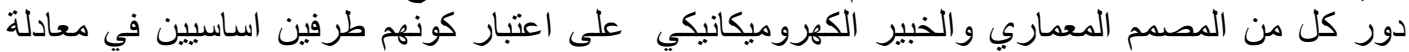
اختيار انظمة التكييف في المباني ـ ذلك ان التناقض في وجنتي نظر كلي كل من الطرفين سابقى الذكر يتضح جليا

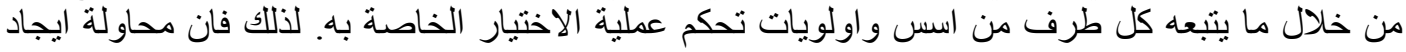

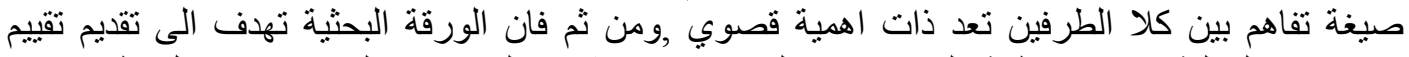

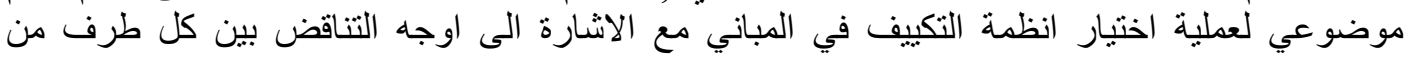

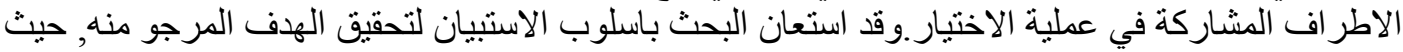

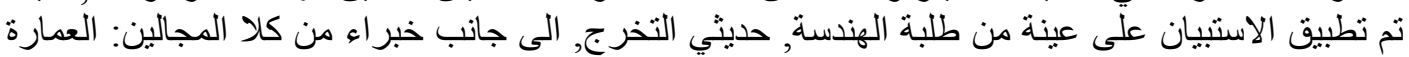

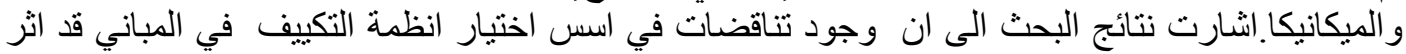
بالفعل على كفاءة عملية الاختيار كما هو موضح النح تفصيلا. 